\title{
Justification of safe and effective working conditions for pit reserves of "Pioner" gold deposit
}

\author{
Marina Potapchuk ${ }^{1 *}$, Gennady Kursakin, Viktor Krukov ${ }^{1}$ and Mikhail Lomov ${ }^{1}$ \\ ${ }^{1}$ Mining Institute of Far eastern branch of Russian Academy of Sciences, Khabarovsk, Russia
}

\begin{abstract}
Further prospects for the development of "Pioner" gold deposit are associated with the development of deep-seated ore bodies by an underground method. When assessing the bump hazard of proposed technological solutions for stripping and working out the pit reserves of the deposit and substantiating the safe working conditions, some comprehensive studies were carried out, including an analysis of the geological and geomechanical conditions of deposit's development, detailed study of the physical and mechanical properties of rocks and ores, investigation of the fracture tectonics of the deposit and stress and strain state of the rock massif of the deposit. The performed modeling of the geomechanical processes of the rock massif with the use of numerical methods made it possible to identify the safe parameters of the guarding safety pillars under the pit bottom, and also to identify areas and elements of rock structures characterized by a minimum margin of stability according to the criteria of the acting maximum compressive and tangential stresses after complete mining of ore bodies. Recommendations were developed on the rational order of mining of ore bodies and on effective ways to protect and maintain mine workings.
\end{abstract}

\section{Introduction}

"Pioner" gold deposit is located in Amur region, Zeya district. The deposit is represented by a series of numerous small lenticular bodies of irregular shape, nonpersistent in the fall and strike. Ore bodies fall to the north-north-west at an angle of about 60. The average horizontal thickness is from 2.0 to $6.8 \mathrm{~m}$. The tectonic structure of the deposit is determined by a combination of faults in the orthogonal and diagonal systems.

The formation of the structures of localization of ore-magmatic systems is due to the factors of difference in their internal structure and composition of magmatic rocks. There are five systems isometric in plan view and one oblong. Three of them (I, II, III), being the earliest ones, belong to the diorite-granodiorite assemblage, two $(\mathrm{V}, \mathrm{VI})$, occupying the average age-related position, are represented by the subalkaline-granite kindred (according to the existing ideas, the Jurassic age) and one (IV) - by fluidolite. The isolated systems

* Corresponding author: potapchuk-igd@mail.ru 
occupy a certain spatial position and correspond to a specific structure. Within these structures, 15 mineralization zones are shown, as shown in Fig. 1.

Currently, the development of the Bakhmut ore zone is under way, the upper part of the deposit (N-E Bahmut) has largely been worked out by quarries, further development of deep-seated ore bodies 2-9, 1-5, 1-4 and 10-24 by underground method is planned. The structure of the ore-rock block of the deposit is very heterogeneous due to the combination of heterogeneous rocks (diorite porphyrites, microdiorites, granodiorite-porphyry, fluidolites), metasomatites, different morphology fault structures and breccias. The fracture of the submeridional and north-western strike is divided into blocks of high order $[1,2]$. Two blocks are completely outlined: the first and the second. The first block is composed mainly of diorite porphyrites, which with depth are replaced by fluidolites of pelitic texture. The stability of rocks is reduced in a series of pseudomorphic metasomatites (apodiorites, apogranites) - berezitized rocks - near-ore (automorphic) metasomatites. Their ratio is 30:65:5, respectively. There are two areals with a relatively high density of disjunctive breaks. The second block is composed mainly of pelitic fluidolites, which have a sufficiently high strength. The stability of rocks is reduced in a series of pseudomorphic metasomatites (apodiorites, apogranites) - tourmaline rocks - quartz-tourmaline (automorphic) metasomatites. Their ratio is 25:65:10, respectively. There are four areals of disunctive breaks with relatively high density. The following sections of increased fracturing are identified: falling on the central part of the ore body 1-4, with cracks often being of vein material (quartz, carbonates, tourmaline, carbon minerals), with a thickness of tenths of a millimeter, less often up to $1-5 \mathrm{~mm}$, and adjacent to the drilling chamber, but largely resulting from blasting. On the basis of generalization of the obtained data, the studied section of the deposit was divided into three groups according to the degree of stability, namely: relatively stable rocks that coincide spatially with altered diorites and granites (apodiorites, apogranites) (at least $30 \%$ of the total volume), medium rock stability, berezitized and tourmalineized varieties occupy 60-65\%, and unstable rocks, berezites, quartz-feldspar-chlorite and quartz-tourmaline metasomatites, quartz kalishaspatites - up to $10 \%$.

Based on the mining and geological conditions of deposit's development and in accordance with the Rules for engineering operation of minery developing deposits of nonferrous, rare and precious metals [3] for underground mining of ore bodies, a system was proposed using sub-floor drifts with open worked out space and breaking of ore by deep wells with a diameter of $65 \mathrm{~mm}$ with a height of $30-40 \mathrm{~m}$, a sub-floor being $15 \div 20 \mathrm{~m}$.

The transition to an underground method for the development of ore reserves is associated with a number of complicating factors, such as the impact of borrow cut on the stability of mine workings in the near edge part of the massif, the presence of sites with various rock disturbances, and the complex tectonic structure of the deposit. In order to obtain reliable geomechanical information necessary for the development of recommendations on the rational order of mining ore bodies, and effective methods of protection and maintenance of mine workings, a set of studies was carried out, including geodynamic zoning of the deposit with the identification of its tectonic structure, study of the properties and stress state of the rock massif, as well as the study of stress distribution in the rock massif as the deposit was being mined. 

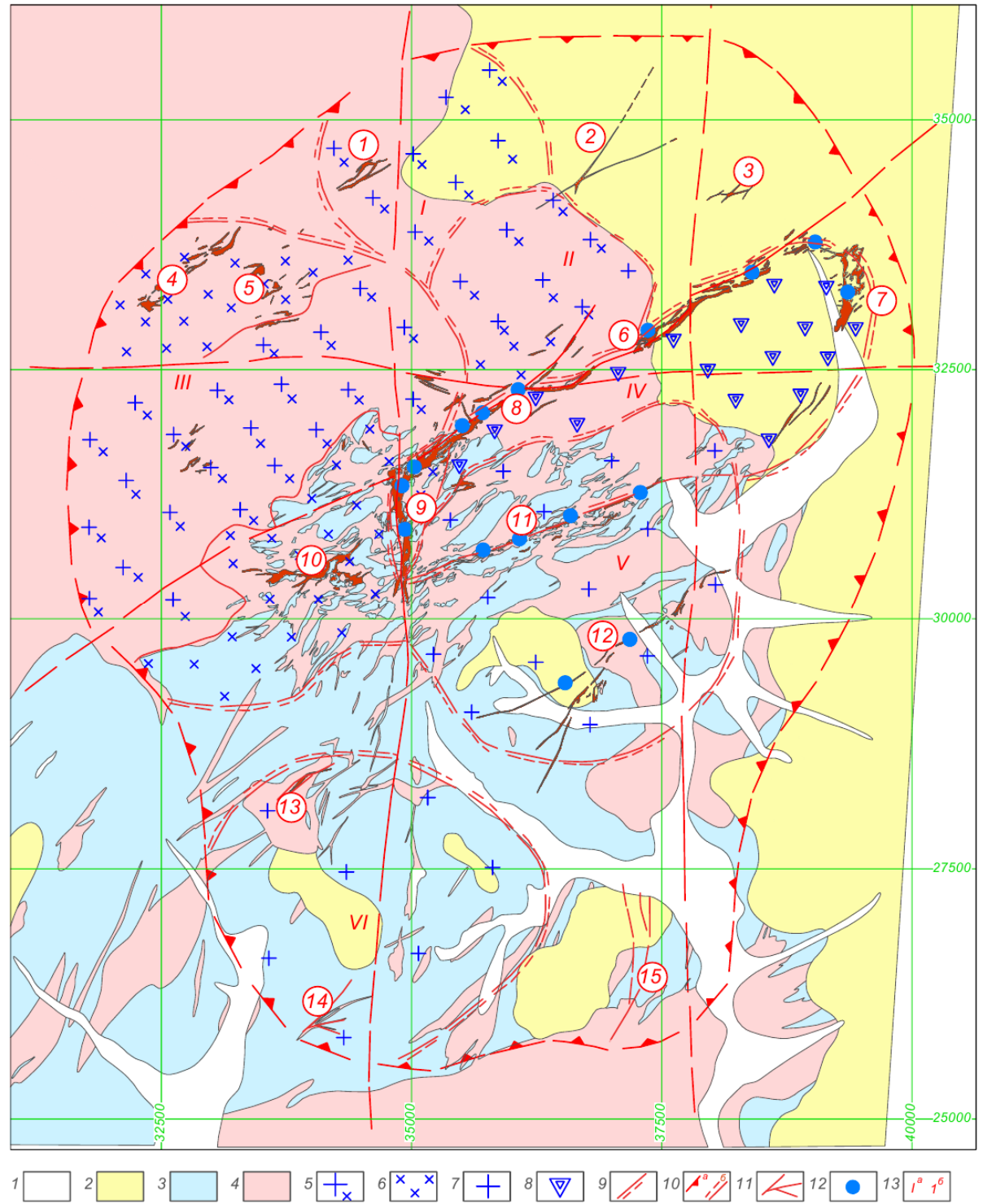

1. Quaternary sediments 2. Neogene-Quaternary sediments; 3. Jura sedimentary complex; 4. Cretaceous intrusive formations; 5. Granodiorites, granodiorite-porphyry, quartz diorite porphyrites; 6. Gabbro-diorites, diorite porphyrites, microdiorites; 7 Subalkaline granites, granite-porphyry; 8. Fluidolites, eruptive and explosive breccias; 9. Boundaries of ore-magmatic systems. 10. Faults: a) bordering the Pioneer arch, b) linear structures traced and distinguished by interpretation, geophysical features; 11. Ore bodies and mineralization zones; 12. Ore posts; 13. Objects: a) structures of localization of ore-magmatic systems; b) ore bodies and zones of mineralization: $2-\mathrm{z}$. Dump, 3 - z. Original, 4 - o.z. Asteriks, 5 - o.z. Asteriks 2, 6 - o.z. Bahmut, 7 o.z. Erosion, 8 - o.z. Intermediary, 9 - o.z. South, 10 - o.z. East, 11 - o.z. Andreevskaya and Contacting, 12 - o.z. Nikolaevskaya, 13 - o.z. Babaevskaya, 15 - o.z. Propsective

Fig. 1. Structure of ore-magmatic systems of ore field Pioneer 


\section{Materials and methods}

In order to study the regularities in the process of anthropogenic impact in the distribution of initial stresses in the rock massif (in the pillars and the main structural elements of the mining system), the computational method (the finite element method) used widely for solving various geomechanical problems was applied $[4,5,6]$.

The applied method was implemented with the help of the FEM software package consisting of three modules: FEM1 (for the volumetric problem - FEMV1), FEM2-3 (FEMV2-3), and FEM4 (FEMV4), allowing solving the problems of the theory of elasticity and plasticity by the finite element method, both in plaane and in volumetric formulations. The program allows the assignment of homogeneous and non-homogeneous massifs with any kind of heterogeneity: ore bodies with different angles of inclinations, workings of different configurations [7].

When assigning loads along the boundaries of the finite element model, the results of an experimental evaluation of the stress state parameters using the acoustic-emission memory effect $[8,9]$ were used, and also the fact that the natural stress field of the upper (upland) part of the massif is determined by the influence of the modern relief and at a depth below the bottom of the valleys, tectonic forces that form the tectonic component of the stress tensor begin to act. Therefore, the depth and upland parts of the massif were differentiated according to the level of the initial stresses, supposing that the gravitational stress field, described in accordance with the well-known hypothesis of Dinnik [10], acts in the upper part of the deposits.

To obtain objective information about the properties and state of the rock massif used in the modeling, the geodynamic zoning of the deposit site was carried out, during which its tectonic structure was studied, including the separation of the boundaries of tectonic blocks by geological and morphometric methods, and the physico-mechanical characteristics of the entire lithological complex were found.

\section{Results and discussion}

An analysis of the geodynamic position of "Pioner" deposit in the modern structure of the Amur plate showed that it is confined to the region of compression with a shift [11]. According to the results of the morphometric analysis of the relief from satellite geodesy data and seismic survey materials [12-15], it was established that the compression mode is typical for the deposit area and the vector of the current main horizontal compression at the site is directed south-west-westwards.

To assess the stress state, a method based on the well-known Kaiser effect was also used, according to which rocks have the ability to store, keep and reproduce the information on the stresses experienced [9]. According to the results of the research, it is established that the Kaiser effect is manifested in $30 \%$ of the samples studied, sampled at a depth of more than $80 \mathrm{~m}$, in which the spread between the measured and calculated values of $\sigma_{0}$ to $\sigma_{k}$ does not exceed $30 \%$. The obtained results indicate that the stress state at the depths of sampling $(80-200 \mathrm{~m})$ is close to hydrostatic, due to the weight of the overlying rock mass.

The generalization of the set of data obtained made it possible to substantiate the parameters of the stress field in the region of the deposit, which is characterized by a gravitational type up to a depth of $320 \mathrm{~m}$, while horizontal compressive stresses oriented in south-westwards and 1.5-2 times higher than the vertical stresses predominate below.

The evaluation of the stressed-strain state of "Pioner" rock massif was carried out in three stages: first, a change in the level of stresses at individual points in the massif was studied with a decrease in the height of the safety pillar during the mining of ore bodies; further, the degree of influence of tectonic structures on the distribution of stresses in the 
elements of rock structures and the surrounding rock massif was established, and at the final stage the assessment of the applied development system from the position of bump hazard was carried out.

Studies of the geomechanical state of the ore-rock massif and ore bodies 10-24 and 1024-1 and pillars decreasing during the process of mining under the bottom of the quarry have shown that a complex anthropogenic stress field is formed characterized by the presence of both discharge areas (mainly in the quarries and separate areas under the bottom of the quarry), and the appearance of zones of increased stress concentrations in the marginal parts of the massif. Prior to the beginning of mining, two regions of high stress concentrations were identified: at the interface between the bottom and the lower side of the quarry along the southeastern border of the quarry, and in the deep part of the deposit in the northwestern part of the quarry below the horizon of $140 \mathrm{~m}$. The level of maximum compressive stresses in these sections exceeds $12.5 \mathrm{MPa}$, the tangential stress level is 5.5 $\mathrm{MPa}$. Unloading zones are observed mainly along the bottom and sides of the quarry, the magnitude of the maximum tensile stresses here does not exceed $0.5 \mathrm{MPa}$.

As the ore bodies are being worked out and the height of the guard pillars decreases, a redistribution of stresses and a formation of new areas of increased stresses occur. The site, which is formed on the boundary of the enclosing massif and the worked out space at $155 \div$ $165 \mathrm{~m}$ mark, at the final stage of mining the ore body $10-24$ is characterized by the maximum values of compressive and tangential stresses, reaching 19 and $6.8 \mathrm{MPa}$, respectively. In the safety pillars of ore bodies 10-24-1 and 10-24, the stresses amount to 15 MPa.

For the geomechanical justification of the limiting parameters of the safety pillars, the theory of maximum normal compressive stresses and the Coulomb-Mohr criterion was used. The calculation of the stability of the most stressed sections according to these criteria showed (see Figure 2) that stability is maintained only at a height of safety pillars beinbg 20 $\mathrm{m}$ for profile lines 486, 482 and $23 \mathrm{~m}$ for profile line 484 .

The results of volumetric modeling of successive stages of ore blocks mining in the following sequence: block 1-5, block 2-9 showed that before the beginning of mining of ore bodies, the maximum stress concentrations are observed along the northwest and southeast boundaries of the quarry at the interface between the bottom and the lower slope.

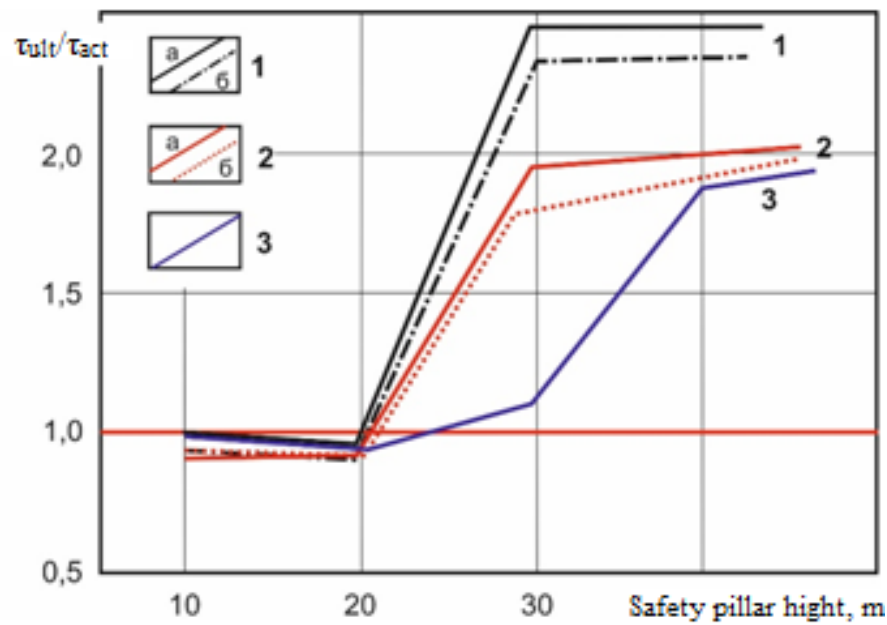

1 - for conditions of profile 486 ( $a$ - for pillar 10-24, $b$ - for pillar 10-24-1); 2 - for conditions of profile 482 ( $a$ - for pillar 10-24, $b$ - for pillar 10-24-1); 3 -for conditions of profile 484 for pillar 10-24 Fig. 2. Dependence of the change in the ratio of the acting tangential stress in the rock mass to the ultimate shear strength of rocks $\left(\tau_{\text {ult }} / \tau_{\text {act }}\right)$ on the safety pillar height. 
The values of the maximum compressive stresses in these sections do not exceed 15 $\mathrm{MPa}$, the shear stresses are $10 \mathrm{MPa}$, respectively.

Working out part of the ore reserves of the upper sub-floor $(115 \div 130 \mathrm{~m})$ in the area of the ore block 1-5 leads to a redistribution of stresses and formation of an area of increased rock pressure in the vicinity of the bottom of the lower sub-floor, with a tangential stress and medium pressure level reaching $13 \mathrm{MPa}$, indicating an increased probability of destruction of this section of the massif in a static form (Fig. 3).

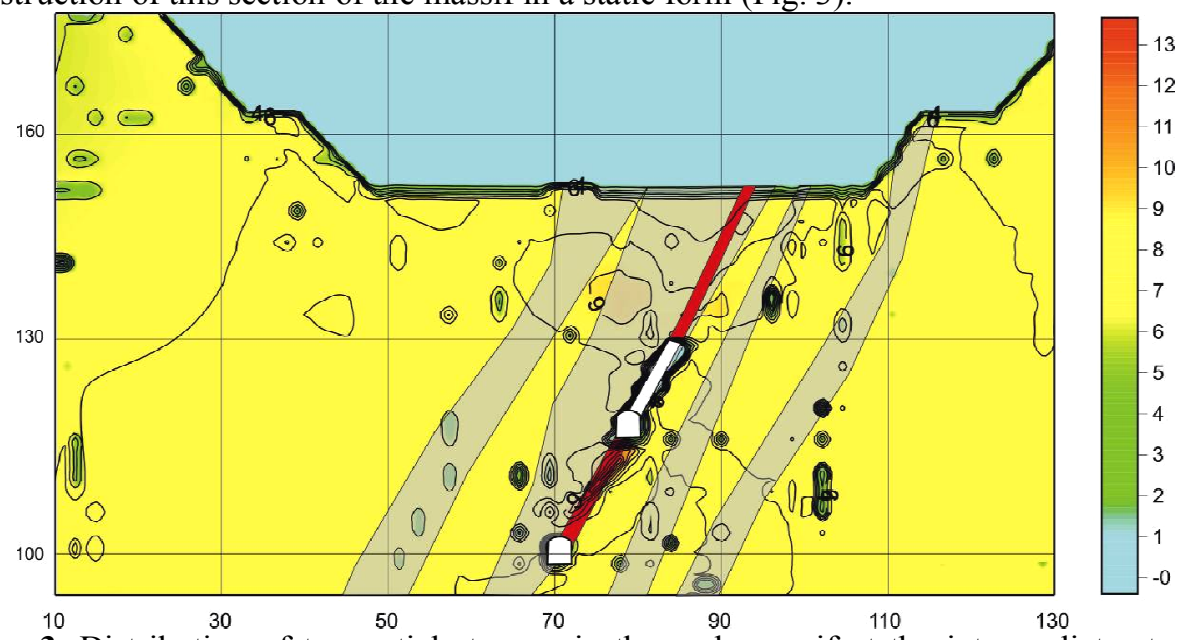

Fig. 3. Distribution of tangential stresses in the rock massif at the intermediate stage of mining ore block 1-5

At the final stage of mining of ore block 1-5, the voltages are concentrated in the lower part of the safety pillar and at the section below the sub-floor drift of horizon $100 \mathrm{~m}$. The maximum compressive stresses increase by $40 \%$, and reach $20 \mathrm{MPa}$, but the tangential stresses decrease, compared to the intermediate stage of $2 \mathrm{MPa}$ and constitute $10 \mathrm{MPa}$.

Partial mining of the ore sub-floor $115 \div 130$ m of block $2-9$ leads to the formation of an additional area of increased stresses in the rock mass along the sides of the chamber's exhausted space, but the stress level does not increase significantly, only by $0.5 \mathrm{MPa}$ from the stresses to the beginning of working. After the complete excavation of this ore block, the maximum stresses are concentrated at the section of the rock massif below the sub-floor drift of horizon $100 \mathrm{~m}$. The values of the maximum compressive stresses are $16.5 \mathrm{MPa}$, tangential - 10.8 MPa.

\subsection{Conclusions}

The performed geomechanical calculations and modeling results allowed establishing the safe parameters of the guarding safety pillars formed during mining of the reserves of ore bodies 10-24, 10-24-1, excluding the development of deformation processes of the surface with the facilities of the mine's site located, which are 20-23 m .

The main elements of the mining structures of the applied development system will remain stable by the criteria of the acting maximum compressive and tangential stresses at all the considered stages of mining of ore bodies 1-5 and 2-9. But the minimum reserve of stability, calculated by the Coulomb-Mohr criterion, will have an ore massif of the upper sub-floor (above $130 \mathrm{~m}$ ) of ore body 1-5 before the start of the mining and ore body 2-9 during mining.

Based on the results of geomechanical studies, recommendations were developed on the rational order and order of mining of ore bodies, effective ways to protect and maintain 
mine workings, as well as the parameters of the pillars and other structural elements of the mining system.

\section{References}

1. Petrographic Code. Magmatic, metasomatic, metamorphic and impact formation. Ed. 3, St. Petersburg: Publishing house VSEGEI. p. 200. (2009).

2. G.I. Tugovik, Fluid-explosive structures and formation mineralization. Moscow: Nauka. p. 193. (1989).

3. Rules for engineering operation of minery developing deposits of non-ferrous, rare and precious metals, Moscow: Nedra. - p. 109. (1981).

4. A. Houmat Int. J. Numer. And Anal. Meth. Geomech 37, 11, 1552. (2013).

5. S. Shnorhokian, H. Mitri, D. Thibodeau, Int. J. of Rock Mech. and Mining Scien. 66, 13. (2014).

6. I.M. Petukhov, A.M. Linkov, V.S. Sidorov, Calculation methods in the mechanics of rock bumps and blows: Guideline. Moscow: Nedra. p. 256. (1992).

7. O.V. Zoteev, Higher education bulletin of Mining Journal. 5, 108. (2003).

8. T. Kanagawa, M. Hayashi, H. Report 375017 Centr. Res. Inst. of Electric Power Ind. (CRIEPI) (1976).

9. V.S. Yamshchikov, V.L. Shkuratnik, K.G. Lykov, Physical and technical issues of mineral wealth. 2, 23. (1990).

10. I.A. Turchaninov, E.V. Kasparian, Fundamentals of the mechanics of rocks Leningrad: Nedra. p. 488. (1989).

11. B.G. Saksin, I.Iu. Rasskazov, B.F. Shevchenko, Physical and technical issues of mineral wealth. 2, 53. (2015).

12. V.I. Usikov, Tectonics, Magmatism and Geodynamics of the East of Asia: VII Kosygin Readings: Proceedings of the All-Russian Conference Dynamics and Structure of Tectonic Flows. 328. (2011).

13. K.G. Levi, S.I. Sherman, V.A. Sankov, Map of modern geodynamics of Asia. Siberian Division of RAS. (2007).

14. S.V. Ashurkov, V.A. Sankov, A.I. Miroshnichenko, A.V. Lukhnev, A.P. Sorokin, M.A. Serov, L.M. Byzov, Geology and Geophysics. 2, 299. (2011).

15. I.Iu. Rasskazov, Pacific Geology. 25, 104. (2006). 